\title{
Legislation introduced to regulate water quality on reserves
}

Published at www.cmaj.ca on June 2

$\mathrm{N}$ ew federal legislation that would eventually establish drinking water and wastewater standards on reserves begins to address important public health issues but must be accompanied by adequate financial resources, says the Assembly of First Nations (AFN).

The short bill - which must still pass the Senate and House of Commons to become law - essentially allows the federal government to work with each province and territory to draft water quality regulations for reserves consistent with the standards of those jurisdictions. It was tabled by Indian Affairs Minister Chuck Strahl and Health Minister Leona Aglukkaq in the Senate on May 26.

"First Nations (communities) should expect, as do all Canadians, to have access to safe, clean drinking water," Strahl said in introducing Bill S-11, the Safe Drinking Water for First Nations Act.

Currently, residents of more than 100 First Nations communities across Canada live under drinking water advisories, and close to 50 First Nations water systems are classified as "high risk," meaning they cannot produce safe water, according to the AFN.

"This is a step in the right direction as it will provide us with another mechanism to help protect the health and safety of all First Nations living onreserve," Aglukkaq said.

The legislation is not yet accompanied by regulations, or funding.

However, Ottawa announced while unveiling the fiscal year 2010/11 budget in March that over the next two years, it will add another $\$ 330$ million to an initiative called the First Nations Water and Wastewater Action Plan.

The promise followed recommendations from the Expert Panel on Safe Drinking Water for First Nations in 2006 that called on the federal government to close the regulatory gap regard-

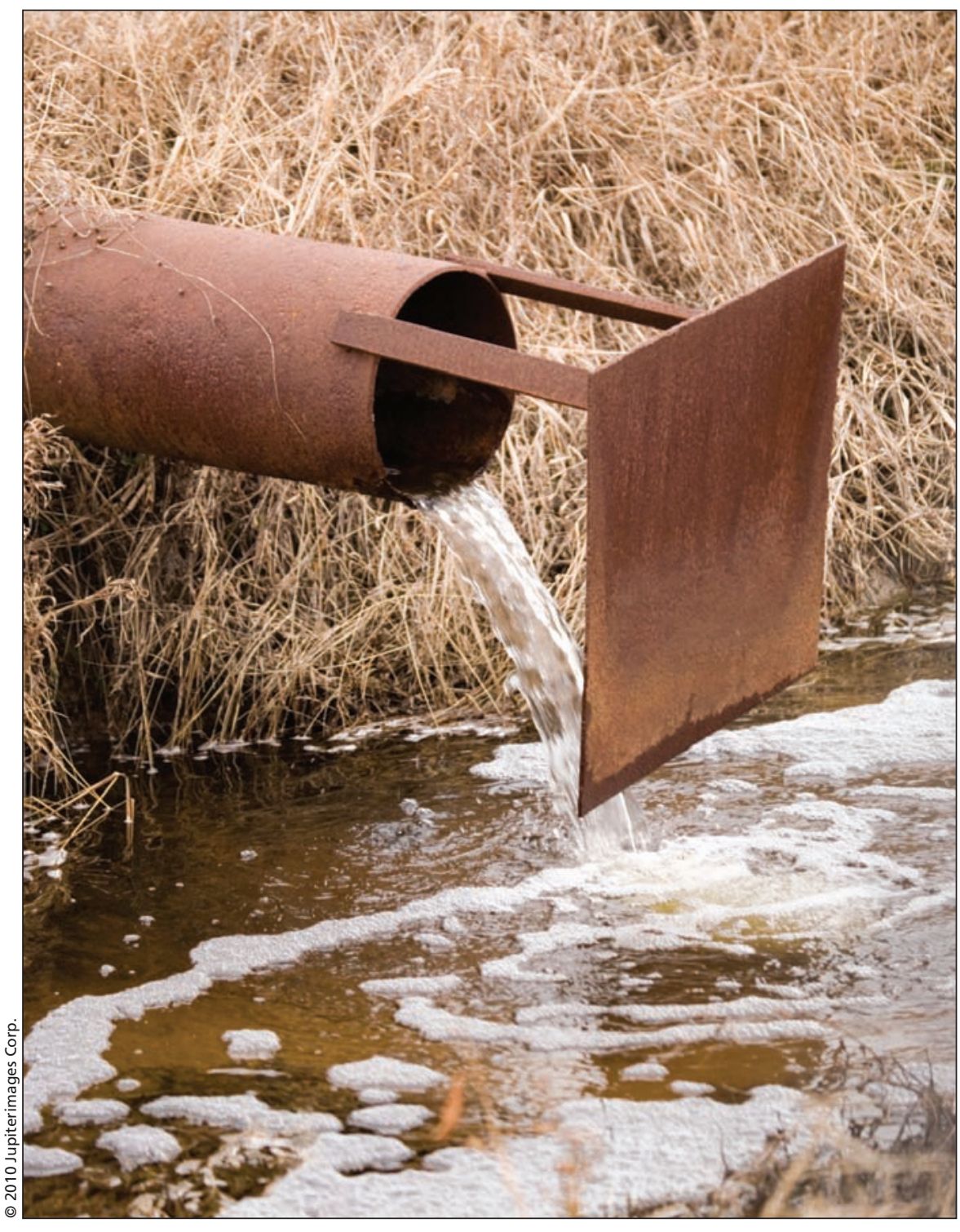

Residents of more than 100 First Nations communities across Canada live under drinking water advisories, and close to 50 First Nations water systems are classified as "high risk," meaning they cannot produce safe water.

ing the quality of water and wastewater treatment on reserves. Both a Senate committee and the commissioner of environmental sustainability have issued similar calls.

The legislation "meets the recommendation that there should be a regulatory regime in place," says Irving Leblanc, the AFN's special advisor on water. "But it did not meet the very important precondition that the resource gap needs to be addressed first, before you can even contemplate implementing regulations."

The AFN's main concern is that the increasing costs of infrastructure projects across the country will make it difficult to bring First Nations' water and wastewater systems up to provincial standards. Leblanc says that will 
require more capacity than communities have and more resources than Ottawa has committed.

Steve Hrudey, one of the three members of the Expert Panel on Safe Drinking Water, echoes those fears. The legislation is "a necessary step - that's the most tangible thing you can say about it," he says. "Obviously, one wonders how it took four years to produce this. ... This is only an enabling concept. As I'm sure most people will comment, the devil will be in the details."

Resources must go hand-in-hand with the regulations, says Hrudey, professor emeritus at the University of Alberta in Edmonton. "My concern is that there needs to be a recognition of the overriding importance of the people factor in all this. Basically, investment in training and support for [plant] operators is almost a deal maker. If you don't single that out and make sure that happens, investment in other areas just building plants or establishing detailed regulations - is not going to give you the assurance you need."
Currently, a federally funded, circuit-training program that began in Saskatchewan has been successful in sending trainers to remote First Nations to teach community members how to maintain and operate water treatment infrastructure. "What we need is lots more of that," Hrudey says. "The reality is they don't have enough money to send enough people to get around to the plants as frequently as they need to."

If Bill S-11 passes, the federal government will examine existing provincial/territorial laws around water safety and quality, and then work with First Nations communities and leaders to adapt them to their specific needs, says Karl Carisse, senior director of strategic initiatives for Northern and Indian Affairs.

The law will allow First Nations and municipalities to work together on training options and will eventually result in drinking water standards, operator certifications and wastewater treatment standards that are comparable to provincial or territorial standards off- reserve, Carisse says. "It will take several years before every community in Canada has regulations in place, but the intent will be to work forward, hopefully with one region, at first."

After the first region has put regulations in place, Indian and Northern Affairs hopes to roll out several others each successive year.

Meanwhile, the federal government is completing an assessment of water and wastewater needs in all First Nations communities, following the advice of the Senate committee. That report is expected to be publicly available this winter.

The federal government recognizes the need for financial resources and training to accompany regulations, Carisse adds. "We have to make sure that after we move forward developing regulations that First Nations can meet those regulations. We don't want to set anybody up to fail." — Laura Eggertson, Ottawa, Ont.

DOI:10.1503/cmaj.109-3275 